\title{
Regeneration of Cucumis sativus from Cotyledons of Small Explants
}

\author{
Nawab Ali, Robert M. Skirvin, and Walter E. Splittstoesser \\ Department of Horticulture, University of Illinois, Urbana, IL 61801
}

Additional index words. cucumber, tissue culture

Many plants regenerated from a single seed would produce more true-to-type plants, facilitate germplasm storage by reducing the amount of seed required, and minimize seedto-seed variation. Shoot regeneration and embryogenesis from cucumber cotyledons (Cade et al., 1987; Chee, 1990) have been reported. We report here the regeneration of complete plants obtained from cotyledon segments of various sizes.

The seedcoat was discarded from 'Burpless Hybrid' cucumber seeds, and the remaining seeds were sterilized in $70 \%$ ethanol for $1 \mathrm{~min}$ and $0.5 \%$ sodium hypochlorite for $10 \mathrm{~min}$ and rinsed three times with sterilized distilled water. Each cotyledon was cut transversely into one, two, four, six, or 24 segments. There were 54 explants each from cotyledons cut into one to six segments and 72 explants from cotyledons cut into 24 segments.

Explants were cultured on $8 \mathrm{ml}$ of Skirvin and Chu's modification (1979) of Murashige and Skoog (1962) medium (MS) supplemented with $4 \mathrm{mg}$ BAP and $0.2 \mathrm{mg}$ NAA/ liter. When shoots were regenerated, they

Received for publication 12 June 1990. The cost of publishing this paper was defrayed in part by the payment of page charges. Under postal regulations, this paper therefore must be hereby marked advertisement solely to indicate this fact. were removed from the cotyledon segment and transferred to rooting medium (MS medium with $1.5 \mathrm{mg}$ NAA/liter). Rooted shoots were placed in soil in the greenhouse and covered with a plastic sheet for 1 week. Data were analyzed by a logistic regression model.

There was no significant difference in the percentage of shoots regenerated from segments at the distal end of the cotyledon compared to those adjacent to the embryonic axis. This result suggests that if endogenous growth regulators that regulate in vitro regeneration are present, they are evenly distributed within the cotyledon.

When cotyledons were cut into 24 segments, only two shoots were regenerated and these were never large enough to be transferred to rooting medium. When cotyledons were cut into six segments, $47 \%$ of the 54 explants regenerated shoots, and 25 of these shoots were grown into rooted plants in soil (Table 1). Cotyledons cut into four segments produced 17 plants and those cut into two segments produced 28 plants. Intact cotyledons regenerated only a few shoots (Table 1) and many died. We suggest that explant expansion resulted in the upper regions being physically separated from the medium so that few nutrients reached these regions. Smaller explants survived longer in vitro and regenerated shoots four days earlier than the larger segments. When cotyledons were cut into six segments, 5.6 plants per seed were regenerated. Cotyledons cut into more or fewer segments regenerated significantly fewer rooted plants (Table 1).

\section{Literature Cited}

Cade, R.M., T.C. Wehner, and F.A. Blazich. 1987. Organogenesis and embryogenesis from cucumber $(C$. sativus L.) cotyledon-derived callus. HortScience 22:1130.

Chee, P.P. 1990. High frequency of somatic embryogenesis and recovery of fertile cucumber plants. HortScience 25:792-793.

Murashige, T. and F. Skoog. 1962. A revised medium for rapid growth and bioassays with tobacco tissue cultures. Physiol. Plant. 15:474497.

Skirvin, R.M. and M.C. Chu. 1979. In vitro propagation of 'Forever Yours' rose. HortScience 14:608-610.

Table 1. Shoot regeneration from cotyledon segments of various sizes. ${ }^{2}$

\begin{tabular}{ccccc}
\hline \hline $\begin{array}{c}\text { Segments/ } \\
\text { cotyledon } \\
\text { (no.) }\end{array}$ & $\begin{array}{c}\text { Segments } \\
\text { with shoots } \\
(\%)\end{array}$ & $\begin{array}{c}\text { First shoots } \\
\text { produced } \\
\text { (days) }\end{array}$ & $\begin{array}{c}\text { Rooted plants/ } \\
\text { cotyledon } \\
\text { (no.) }\end{array}$ & $\begin{array}{c}\text { Rooted } \\
\text { plants/seed } \\
\text { (no.) }\end{array}$ \\
\hline 24 & $<1 \mathrm{a}$ & $22 \mathrm{~b}$ & $0 \mathrm{a}$ & $0 \mathrm{a}$ \\
6 & $47 \mathrm{~d}$ & $18 \mathrm{a}$ & $25 \mathrm{c}$ & $5.6 \mathrm{c}$ \\
4 & $32 \mathrm{c}$ & $22 \mathrm{~b}$ & $17 \mathrm{~b}$ & $2.5 \mathrm{~b}$ \\
2 & $52 \mathrm{~d}$ & $22 \mathrm{~b}$ & $28 \mathrm{c}$ & $2.1 \mathrm{~b}$ \\
1 & $20 \mathrm{~b}$ & $22 \mathrm{~b}$ & $11 \mathrm{~b}$ & $0.4 \mathrm{a}$ \\
\hline
\end{tabular}

2Based on 54 explants of cotyledons cut into one to six segments and 72 explants from cotyledons cut into 24 segments. Mean separation in columns at $P=0.05$. 